\title{
The Influence of Milan on the Development of the Lombard Koiné in Fifteenth-Century Italy: the Letters of Elisabetta of Pavia*
}

\section{Josh Brown}

Abstract: The main tendency characterizing the development of language in Lombardy in the fourteenth and fifteenth centuries is the formation of a koiné. The extent to which Milan influenced the Lombard koiné is the subject of ongoing debate. On the one hand, scholars suggest that Milan provided a centralizing force for the "Milanization" of other Lombard vernaculars, similar to what occurred for Piedmont and the Veneto. On the other hand, studies have pointed out that Milan was not a centralizing force for the Lombard koiné and that it remains to be verified whether the prestige of Milanese influenced non-Milanese vernaculars. This paper looks at the extent to which Milan influenced the koiné in fifteenth-century Lombardy. I consider eight linguistic items, previously described as unique to the vernacular of Pavia, to verify their presence or absence in a corpus of religious writings from the fifteenth-century nun Elisabetta of Pavia and whether Milanese items can be identified. I consider aspects of phonology and morphology in Elisabetta's letters and conclude that her language is best characterized as a pre-koiné. The article concludes by arguing for less emphasis on the role of Milan in histories of the vernacular in Lombardy. This finding has implications for the history of non-literary writing in northern Italy and the importance attributed to capital cities in processes of koineization.

\section{Introduction}

The main tendency characterizing the evolution of the vernacular in Lombardy during the late Middle Ages is the formation of a koiné. ${ }^{1}$ At the same time,

\footnotetext{
* An earlier draft of this paper was presented at the 7th Biennial Conference of the Australasian Centre for Italian Studies (ACIS) at Flinders University and the University of South Australia, Adelaide, 4-6 December 2013.

${ }^{1}$ For a recent survey of studies on old northern vernaculars, see Tomasin.
} 
histories of the vernacular in Lombardy have identified texts that have maintained a strong adherence to local forms of language even as koineization was in progress. Scholars have pointed to the "learnèd" nature of the Lombard koiné, which finds its most elaborate expression in the chanceries and the courts. Paolo Bongrani and Silvia Morgana, for example, describe the koiné as being a "refined product" and a "linguistic end-point which was not immediately accessible" to writers, referring to the case of maestro Galcerando, a doctor who, in a letter from 1483, asks for forgiveness since he was not "uso scriver ala cortezana" (Bongrani and Morgana, "La Lombardia" 1992: 101). ${ }^{2}$

There is ongoing debate surrounding the role that Milan played in the formation of the koiné. On the one hand, scholars have suggested that Milan took on a predominant position in the region (Morgana, Storia linguistica, 25). Ottavio Lurati (485-516), too, suggests that Milan provided a centralizing force for the "Milanization" of other Lombard vernaculars, similar to what occurred for Piedmont and the Veneto. On the other hand, Giovanna Massariello Merzagora proposes that the linguistic history of Lombardy does not revolve around Milan. Glauco Sanga ("Due Lombardie" 181) has provided a synthesis of both viewpoints and suggests that Milan oriented the development of other Lombard dialects, both through its spread of the koine padana antica, as well as through the spread of an Italian model mediated by Milanese over a long period. This paper considers the extent to which Milan influenced the koinè padana antica in fifteenthcentury Lombardy. As a case in point, I consider a series of eight linguistic items, previously described as characteristic of the vernacular of neighbouring Pavia, to verify the presence or absence of these linguistic items in a corpus of religious correspondence. I argue for less emphasis on the role of Milan in the formation of the koiné. ${ }^{3}$ This finding has implications for the language history of Lombardy.

First, I discuss the role that past studies have attributed to Milan in the linguistic history of Lombardy, beginning with those that see its role as central

\footnotetext{
${ }^{2}$ On the koiné more generally, see the collection of essays in Sanga, Koinè in Italia. See also Persico. In a more recent volume, the glossary in Morgana (Breve storia 131) describes the koinè quattro-cinquecentesca as "una lingua diffusa in un ambito regionale più o meno esteso, formatasi integrando le varietà locali demunicipalizzate, il latino e il toscano letterario."

${ }^{3}$ For a study of convergence in modern dialects of Italy, see Trumper and Maddalon. For northern Italy in particular, see Trumper. Sanga ("Lombardy" 259) notes that the modern province of Pavia is a "transition area" and that it "shares features with Milanese, Alessandrino and Ligurian." He says that it is "evolving towards Milanese" even today.
} 
before moving to those who do not. Then, I discuss the fifteenth-century nun Elisabetta of Pavia and how a linguistic analysis of her writing can help to clarify our understanding of the spread of Milanese, or lack of it, in the early fifteenth century. I focus on what attention has previously been paid to convergence in medieval Pavese and what role Milan played in the formation of language in Pavia. ${ }^{4}$

In the most recent study of the linguistic history of Milan, Morgana (Storia linguistica) sees the Lombard capital playing a crucial role in the formation of the koiné, at least for the fourteenth century. During the city's expansionist policy under the Visconti family, Milan assumed a predominant position in the region (25). Describing the inventories of the Visconti library from the fourteenth and fifteenth centuries, Morgana argues that, notwithstanding the significant entrance of Tuscan literature (in primis Dante, Petrarch, and Boccaccio), "le varie forme della cultura municipale (comprese quelle linguistiche) non scomparvero però del tutto, continuarono a sopravvivere tenacemente a livello popolare accanto ai più prestigiosi modelli d'importazione" (26). As evidence, she refers to the vita of Santa Margarita (Wilhelm, De Monte, and Wittum), whose language preserves obvious Milanese traits, or at least western Lombard traits (Morgana 27). Overall, she points to the difficulty of writing an articulated history of the vernacular in Milan given the lack of documentation for non-literary texts of a practical nature, and she prefers to speak of multiple koinai. ${ }^{5}$ The most important phenomenon is decidedly "il passaggio dalle antiche scriptae a quelle formazioni sovramunicipali che sono chiamate lingue di koinè [...] vale a dire di strumenti dotati di una validità e di una diffusione più ampie di quelle possedute dagli antichi volgari municipali" (30).

Angelo Stella sees linguistic convergence in Lombardy as a major tendency in the development of medieval Lombard. After an initial period in which the

\footnotetext{
${ }^{4}$ On the question of when the koiné can be said to have started, see Daniele (229-240). For a recent study of the term "koiné," a concise history of how this term has been used in Italy, and its introduction into Italian, see Regis, "Note su koinè." For a discussion of the terms koinè dialettale and dialetto di koinè with reference to modern Italian, see Regis, "Koinè dialettale."

5 Wilhelm (18n48) notes that "ben poco sappiamo finora sulla scripta milanese." Similar comments are found in Sgrilli (451): "la carenza di fonti documentarie coinvolge tutti i centri lombardi produttivi nel '300'” and then in footnote 99, "eccepisce Mantova, per la quale disponiamo dei solidi materiali dell'Archivio Gonzaga." Colombo (8n16) points out that there is still a lack of studies of non-literary documents: "scarseggiano lavori su testi non letterari (o paraletterari) per i secoli precedenti il XV."
} 
pan-Lombard koiné appeared, Lombard dialects converged from outer areas to form a "modello cortigiano" with Tuscan or Florentine elements also entering at an increasing rate: ${ }^{6}$

la storia linguistica della Lombardia, dalla metà del secolo XIII alla signoria sforzesca, è tra le più esemplari, se non la più esemplare, nel comune processo prima di formazione di coinè municipali, e poi di convergenza, dalle aree laterali, verso un modello cortigiano da una parte, fiorentina dall'altra (153; my emphasis)

Stella's approach to the linguistic history of Lombardy is to canvass what documents are available for each of the major cities. In his section on Pavia, focus is placed on what he calls a "masterpiece of fourteenth-century Lombard prose," the Parafrasi del "Neminem Laedi Nisi a se Ipso» di S. Giovanni Crisostomo, an anonymous work composed circa 1342 (Stella 182). ${ }^{8}$ The Grisostomo exemplifies a "municipal ambition over a regional one" (180), with a style that is still governed by a Latin syntax (182). Maria Antonietta Grignani and Stella described the Grisostomo as being "il più copioso, il più genuino, relativamente de' documenti della parlata pavese antica" (121). Carlo Salvioni used this text in his typology of old pavese to identify four traits that distinguished it from other Lombard varieties ("Dell'antico dialetto pavese" 201). Stella notes that the scripta of Pavia would maintain these grammatical characteristics (palizzate grammaticali) for around a century, that is, until the mid-fifteenth century (183).

\footnotetext{
${ }^{6}$ See Vitale, "Cultura e lingua," for a general overview of language and culture in Milan in the Trecento. Despite the increased and increasing presence of Tuscan in Lombardy throughout the Trecento, Petrarch's arrival in the Visconti court in June 1353 "non avrebbe esercitato invero un efficace influsso per la penetrazione della lingua illustre a Milano e per la nobilitazione del volgare locale" (32). See also the section in Morgana, Storia linguistica, "La prima diffusione dei modelli toscani" (25-29). For a study of early Tuscanisation in merchant texts from Lombardy during the late Trecento and early Quattrocento, see Brown, "Evidence for Early Tuscanisation."

7 That is, "Nessuno ha danno se non da sé medesimo" (Bongrani and Morgana, "La Lombardia" 1992, 92n7).

8 The Grisostomo was first published by Foerster (1880-1883). See Bongrani and Morgana ("La Lombardia" 1994, 105-106) for information on the codex, which had been in the Biblioteca Nazionale di Torino but was destroyed by fire in 1904. On language and dialect in Pavia from the 1300 s to the 1900 s, see Milani and Stella.
} 
The language of the Grisostomo differs from other fourteenth-century Lombard documents, such as the popular religious poetry first studied by Emilio Rho. These are three short hagiographical poems known as the "De sancta Luzia," the "De sancto Andrea," and the "De Sancto baptista," all written "in a generically northern or Lombard language" (Vitale, "Cultura e lingua" 35). Although dated from the Trecento, all three poems are preserved in the fifteenth-century manuscript Ambrosiano N 95 sup., whose verses are "inspired by tosco-umbrian models" (Vitale, "Cultura e lingua" 35). In contrast to writing traditions that maintained a greater adherence to a local scripta, as with the Grisostomo, Antonio Viscardi and Maurizio Vitale have pointed out how the language and form of these documents are elaborated in such a way as to break out from the form and metrical scheme of thirteenth-century Lombard poetry (628).

Bongrani and Morgana ("La Lombardia," 1992) also highlight the importance of the Grisostomo and of Salvioni's studies of its language. Once the linguistic traits were identified, Salvioni was able to specify its provenance as being from Pavia. In addition to the four linguistic elements unique to fourteenth-century Pavese, Salvioni described other characteristics that linked the Grisostomo to old Pavese, as well as to the modern dialect. In sum, Bongrani and Morgana note that Pavia sees itself as "la città distante da Milano e aperta alle correnti piemontesi" ("La Lombardia," 1992: 93). In other words, even though the language in Pavia was slowly incorporating elements of non-Pavese (as all Lombard vernaculars were), its linguistic individuality is still maintained by the end of the fourteenth century, at least in writings of a religious nature. Nevertheless, Milan is characterized as a distant influence.

The role of Milan in the evolution of the koiné is also taken up by Ottavio Lurati. It is significant that, in addition to a division of Lombardy according to geographical categories (western Lombard, Alpine Lombard, the eastern section, western dialects from Trentino, and southern and south-eastern dialects), he prefaces his analysis with two sections, one entirely devoted to Milan and a second on "the spread of the Milanese model" (489). Lurati deals first with the causes of this diffusion and, secondly, the ways in which such a model was spread and may still be spreading. He points to aspects of religious organization in Lombardy, as well as political and historical factors, for the spread of Milanese. In his description of "western Lombard," Lurati refers to the city of Novara, which still today "resta tenacemente aderente alla matrice milanese" (490). In short, Lurati sees Milan as a centralizing force for the "Milanization" of the other Lombard vernaculars. He explains that the heterogeneity of the city, both linguistic and not, has been 
studied from economic, cultural, sociological, and linguistic perspectives, from the dialect of the Lombard valleys to the use of Milanese in literature. He points in particular to the role of religious institutions, the role of the cantastorie ambulante lombardo, as well as one's political affiliation in spreading a Milanese linguistic model throughout Lombardy. His analysis is historical only at times, and it makes references no further back than the Cinquecento.

Conversely, Massariello Merzagora suggests that the linguistic history of Lombardy does not revolve around Milan. In the introduction to her work, she describes the originality of the Lombard situation:

al di là del tipico orientamento dei piccoli centri sul rispettivo capoluogo o centro di prestigio economico nel fatto che Milano e il milanese non esercitino una forza d'attrazione accentratrice sull'intero territorio paragonabile a quella per esempio del dialetto veneziano sulle altre parlate del Veneto o di Torino sull'area piemontese. (6)

She continues to say that it remains to be verified whether the prestige of certain linguistic items that "irradiated" from Milan influenced the supra-municipal regional koiné.

Sanga provides a synthesis of both viewpoints in his review of the two works mentioned above by Lurati and Massariello Merzagora: "Lurati insiste sul ruolo linguistico di Milano, attorno a cui fa ruotare la storia linguistica della Lombardia," but "Massariello lo nega" ("Due Lombardie" 181). Sanga believes that the ambiguity of Milan's role in the linguistic history of Lombardy is due to a misunderstanding. To say that Milan and Milanese exercised a hegemonic function over Lombardy does not necessarily deny the existence or individuality of other local dialects. It means something more complex, namely that Milan oriented the development of other Lombard dialects, both through its spread of the koinè padana antica, as well as through the spread of an Italian model mediated by Milanese over a long period of time. He considers Milan to be a center that linguistically "drained" Lombardy to form a koiné. The formation of a "regional dialect" does not mean that it was used in the whole region of Lombardy; rather, it implies that (a) a supra-regional dialect was formed and used only in certain areas (including the province of Milan, Como, Varese, Sondrio, and the northern part of the provincia of Pavia) and that (b) Milanese acted as a dialetto guida in Lombardy that was superior to the provincial dialects because the Lombard koiné influenced the provincial dialect and, therefore, indirectly, all dialects of the region. 
The extent to which Milan influenced non-Milanese vernaculars and its role in the formation of the koiné are the subject of ongoing debate. If Stella's claim that the eight characteristics unique to Pavese would be maintained until the midfifteenth century, they should be present in the semi-literary writing of a nun from Pavia, known as suor Elisabetta of Pavia, whose writings date from this period.

\section{Suor Elisabetta of Pavia}

There are few biographical details available on suor Elisabetta of Pavia. Rano (665), in his description of the religious order to which Elisabetta belonged, the Annunziate di Lombardia, describes her as "Priora Elisabetta de Rainectiis," who, in 1446, turned to the Pope on behalf of the order to clarify certain matters of ecclesiastical practice. A historian of the seventeenth century, Nicola Crusenio (?-1629), refers to her as "Elisabeth de Rainectiis Priorissae, et sororum domus dell'Annuntiata Papiensis Ordinis S. Augustini” in part LV of his Monasticon Augustinianum. ${ }^{9}$ The only other reference to her that I have found is in Lucia Sebastiani's work (209), where it is noted that conversations between a nun from Milan, Margherita Lambertenghi, and the Mother Superior of Pavia at this time, Antonina de Piscariis, were related through letters by "una certa Elisabetta."

A greater understanding of Elisabetta's role in the order of the Annunziate and her relationship to her addressee, Margherita Lambertenghi (?-1454), is possible through a brief description of the order itself. This will help to clarify the close relationship between Milan and the order and ultimately to show its effect on Elisabetta's language (described in detail in section 4).

The Annunziate di Lombardia ${ }^{10}$ were an order of nuns whose origins date back to the foundation of a convent dedicated to the Annunziata in Pavia in 1408. ${ }^{11}$ In 1407, on the Feast of the Annunciation, three noble Venetian wom-

\footnotetext{
${ }^{9}$ Part LV of the Monasticon Augustinianum is entitled "De origine Congregationis Monialium Augustiniensium sub titulo SS. Annuntiatae," available at

http://www.cassiciaco.it/navigazione/monachesimo/historia_ordinis/storiografi/crusenio.html

${ }^{10}$ Rano (664) notes that the Order was also known as the Annunziate di S. Ambrogio and di S. Marcellina.

11 The rest of the information about the Annunziate in this section is taken from Rano; see Rano's bibliography for further details on the Order. Elsewhere, the Annunziate are mentioned in passing by Annalisa Albuzzi (168n124), who notes that "la carica di superiora generale fu
} 
en-Dorotea Morosini, Eleonora Contarini, and Veronica Duodi-decided to found a monastery under the name of the Annunziata. To this end, they began a pilgrimage to Loreto (near Ancona) and then to Rome. On their way to Rome, in Macerata, they met four women from Pavia who had the same goal. Their names were Isabella Carnecia, Giovanna Stanga, and Michelina and Margherita Gundini, who were sisters. The two groups of women decided to found a monastery in Pavia, which was eventually established on the day of the Epiphany of 1408, next to the church of San Giorgio in Broglio.

In the same year as the Order's foundation (1408), the Benedictine monk Gregorio Beccaria (originally from Pavia), prepared the constitution for the Order, which was approved on 3 July 1447 by the apostolic delegates of the region. This constitution was an adaptation of the constitution already established for the community of Santa Marta in Milan, to which one of suor Elisabetta's addressees, Margherita Lambertenghi, belonged. Santa Marta had been founded earlier, in 1345, and had adopted the Rule of St. Augustine in 1405. Santa Marta therefore considered itself the "mother house" of observance for the Pavia community and of the other convents that eventually united with the Order. It is for this reason that the women of Pavia and of Milan considered themselves to be members of the same community.

The importance of the Order derives from the fact that the women constituted "un Ordine femminile esente e centralizzato" (Rano 664), with a priora generale who visited the other monasteries periodically and who was generally accompanied by two compagne. The priora generale was the priora of the convent of the Annunziata di Pavia. The nuns were initially called beghine, that is, groups of women living together for a spiritual purpose, but who did not follow a religious rule. ${ }^{12}$ Eventually, the Annunziate adopted the Rule of St. Augustine and became a monastero di osservanza in 1445 (Forzatti Golia 149). ${ }^{13}$

introdotta solo alla fine del medioevo, per le santucce, le annunziate di Lombardia e per le francescane della beata Angelina."

${ }^{12}$ On beghine in the Middle Ages, see Mens.

${ }^{13}$ See also Forzatti Golia 153n78, where the monastero dell'Annunciata is listed as being part of the "ordini riformati de observantia quali emergono dall'esame della situazione pavese nel tardo medioevo." Bruni ("Appunti sui movimenti religiosi” 3) observes that "il termine di «osservanza» indica il ripristino del rispetto della regola originaria dei diversi ordini, un accentuato rigorismo morale, un recupero della matrice pauperistica." 
Over the course of the fifteenth century, the Annunziate di Lombardia founded communities in Albenga (prov. of Savona), Alessandria, Asti, Como, Cremona, Genoa, Piacenza, Rimini, Tortona, Valencia, Venice, Vercelli, and Voghera (Rano 667). The monastery in Pavia was one of those to which Isidoro Isolani alludes in 1517 in the vita of the blessed Veronica da Binasco when he says, "huius quoque religionis propago per multas Italiae partes coenobia construxit." The Order of the Annunziate slowly disappeared due to the suppression of monasteries or the passing of individual houses to other Orders. The monastery of Pavia, which in 1576 had 30 religiose and was still blossoming in 1699, disappeared with the suppressions of the eighteenth century and start of the nineteenth century. ${ }^{14}$

The influence of Milan over the entire order is highlighted when one considers that, in order to set up the monasteries of Tortona, Pavia, Como, and Rimini, nuns were taken from the monastery of Santa Marta in Milan and placed in these other monasteries. From these details, one gains a clearer picture of the relationship between the two communities of Milan and Pavia, the connection between suor Elisabetta and Margherita Lambertenghi, and the reciprocal nature of the nuns' relationship.

\section{Methodology}

The letters of suor Elisabetta of Pavia are held in the Archivio di Stato in Milan. These documents were described by Vitale as "copie di lettere fra Suor Margherita e la madre superiora del convento della S. Annunciata di Pavia." Although the documents are not dated, Vitale describes them as "testi quattrocenteschi inediti" and has carried out a brief linguistic analysis to show 25 linguistic phenomena that he considered to be "non o debolissimamente riscontrati nella lingua cancelleresca" ("La lingua volgare della cancelleria sforzesca" 371n134). ${ }^{15}$ Stella's study reports eight phenomena (183), first identified by Salvioni ("Dell'antico dialetto pavese" 201), which are unique to the vernacular of Pavia in the panorama of fifteenth-

\footnotetext{
${ }^{14}$ The inserto cartografico in Caprioli, Rimoldi, and Vaccaro (following p. 424) provides a list of insediamenti religiosi in which the Agostiniane Annunziatine - Annunciazione are listed under the heading Pavia (femminili). The map of medieval Pavia on the following page provides the precise location of where the monastery was located.

15 Brown ("Language Variation") has shown how these 25 elements are only rarely present in a corpus of letters written by merchants from Milan and are therefore evidence for a more nuanced understanding of language variation in fifteenth-century Lombardy.
} 
century Lombard dialects. My method has been to verify the presence or absence of these phenomena in Elisabetta's letters, and to ascertain the presence or absence of Milanese linguistic items by comparing Elisabetta's language to similar forms found in contemporary texts. These eight phenomena are reported below:

1. the dropping of velar and dental $-g$ - (e.g., domenee 'domeniche')

2. $-r-<-\mathrm{dr}-$ and -tr- (e.g., pare, mare, laron)

3. the substitution of velar $-g$ - for $-d$ - (e.g., megaglie 'medaglie', fiaga 'fiata', etc.)

4. -é <-ello (e.g., fraé, quaré, corté, etc.)

5. the 1sg. verbs (e.g., von 'vado', don 'devo', ston, fon)

6. the ending -àno for $3 \mathrm{pl}$. verbs of the 2 nd and $3 \mathrm{rd}$ class (e.g., seguan, reçan, tenan)

7. the ending -ómola for $1 \mathrm{pl}$. verbs, in alternation with -émo (e.g., soma 'siamo', veromo 'verremo')

8. $-\dot{o}<-\mathrm{atu}(\mathrm{m})$ in verbs of the 1 st class (e.g., despogliò 'spogliato', durò 'durato')

Of these eight phenomena, the first four are phonological, which I present first in section 4 below. The other four are morphological, and are discussed in a broader presentation of the morphology of the letters.

Five of the documents exchanged between Elisabetta and Margherita have previously been transcribed in a study of a sixteenth-century suora from the same convent as that of Margherita (Bacchiddu 241-236). ${ }^{16}$ Of these five documents,

\footnotetext{
16 These documents are located in the Archivio di Stato di Milano, Fondo di Religione, n. 2146. The Fondo di Religione contains approximately 7,000 buste and registri from the ninth to the eighteenth century. Within this fondo, the documentation is ordered geographically according to provincia, but with Milan appearing at the start of this order. Each provincia is listed in alphabetical order and then further divided into abbazie, commende, capitoli, confraternite, monasteri, and conventi. The documentation on Santa Marta appears under monasteri, which itself contains different carteggi. The carteggio with documents pertaining to Santa Marta contains just over 50 fascicoli (as well as a series of loose folios) pertaining to the history of Santa Marta from 1280 to 1798 . Within the Santa Marta carteggio, the letters of suor Elisabetta are contained in fascicolo 4. On the cover of fascicolo 4, the date 1400 is written in the top left-hand corner, as well as the following text:
}

Fatto circa il monastero di Sancto Marco nel borgo di Vico di Como, e come la signora Margherita Lambertenghi siasi da questo partita, e portatasi in quello di Sancta 
two are letters written by suor Elisabetta. ${ }^{17}$ These two documents constitute the corpus for the present study.

The collection of texts edited by Grignani and Stella provides a transcription of the statutes of the confraternity of the Raccomandati di S. Maria di Pavia, along with a series of prayers, lists of affiliati, and their professions in texts of the fourteenth and fifteenth centuries. They note that "il dialetto pavese è scarsamente documentato per l'età antica" (Grignani and Stella i). I have made particular use of their volume in referring to similar forms of language in Elisabetta's letters below.

The remainder of this article presents a description of the language of Elisabetta's letters.

\section{The language of the letters of suor Elisabetta of Pavia}

\subsection{Phonology}

\subsubsection{The dropping of velar-g-}

In old Lombard, intervocalic - $g$ - is sometimes maintained, e.g., magon 'stomachino' (Rohlfs \$217); other times, it disappears (dua; old Bergamasco, aóst 'agosto’). ${ }^{18}$

In Elisabetta's letters, there are no cases of the dropping of velar and dental -g-. Examples: adeguarli (I: 82); castigate (I: 64); congregatione (I: 7, 37); miga (I: 15, 69); obligat-ale (I: 8, 15, 66, 68); segondo (I: 41; II: 14); seguire (I: 56).

\subsection{2-r-<-dr-and $-t r-$}

Rohlfs ( $\$ 260$ : - tr-) notes that there is passing of $t r>d r$ "in Italia settentrionale," and that a subsequent development led to $d r>r$, and he quotes examples from

\section{Martha di Milano con successivo fatto dei progressi del medesimo monastero di Sancta Martha.}

The bottom left-hand corner of the folio contains the following text:

Per il Monas.o di S. to Marco di Como / unito a quello di S.ta Marta di Mil.o / Tit.o

Origine, e Progresso del Mon.so / Mazzo primo.

For further details on the Fondo di Religione, see Natale, Bellù, and Bazzi (960-961); Santa Marta is mentioned on p. 964.

${ }^{17}$ These are documents 3 and 6 in fascicolo 4 of the Fondo di Religione. I have checked Bacchiddu's transcriptions against the original manuscripts for accuracy.

${ }^{18}$ Degli Innocenti (57) and Rohlfs (\$217) also record the maintenance of - g-. Other outcomes from intervocalic -G- are (1) > - v- (Borgogno 58); (2) > - (Rohlfs \$217). 
antico padovano, i.e., pare, mare, norigar, parón, poré 'potrò' The next section in Rohlfs (\$261: -dr-) notes that "in antico lombardo e in antico padovano la $d$ si assomiglia a $r$," i.e., verà, verrà 'vedrà'.

In Elisabetta's letters, there are no cases of assimilation to $-r$-. Examples from her letters are madre (I: 2, 2, 5, 12, etc.; II: 1, 2, 3, 5, etc.); padr-e/i (I: 14, 67, 77; II: 10) and one case of dre 'indietro' (I: 85).

\subsubsection{The substitution of velar $-\mathrm{g}-$ for $-\mathrm{d}-$}

In their discussion of the Leggenda di S. Maria Egiziana, Angelo Stella and Cesare Repossi (8) note that the substitution of intervocalic dentals with $-g$ - is one of the most characteristic traits of old Pavese; they quote the examples privaga 'privata', nuriaga 'nutrita', cortiaga 'corteggiata', fiaga 'fiata', spaghe 'spade', megaglie 'medaglie', nuga 'nuda'. Grignani and Stella (134) record "tre casi di $g$ da T, D: vege 'vede', dagi, day, dai 'dadi', loghomo 'laudemus'."'

In Elisabetta's letters, $-g$ - has remained intact. Examples are adeguarli (I: 82); castigate (I: 64); congregatione (I: 7, 37); miga (I: 15, 69); obligat-ale (I: 8, 15, 66, 68); segondo (I: 41; II: 14); seguire (I: 56).

\subsection{4 -é <-ello}

Rohlfs (\$1082) explains that the suffix -ellus $>-e$ derives from the union of -ulus with lexemes having the final consonant $r$, such as ager $>$ agerulus $>$ agellus and liber > libellus, but he gives no indication regarding the outcome of this form in northern varieties. ${ }^{20}$ Grignani and Stella (122, point d) describe this phenomenon as the "tacere del $-l l \mathrm{di}$-ello" and note that it continues in modern Pavese (capé 'capello', üsé 'uccello'). The other example they include is bué 'budello' in the sonnets of Lancino Curzio (1460-1512).

The only variant in Elisabetta's letters presents the common Lombard form -ellale in sorell-ale (I: $3,9,35){ }^{21}$

\footnotetext{
${ }^{19}$ Other outcomes from Latin -D- that I have found in northern texts are (1) > - (Degli Innocenti 60; Rohlfs $\$ 216$; Salvioni 213; Sanga 82; Vitale 81); (2) > -z- (Bongrani and Morgana, "La Lombardia” 1994, 105n27; Rohlfs $\$ 276$ and \$277); (3) >-d- (Bertoletti 240; Sanga 82).

20 The only reference to a northern variety follows his comment that "per la formazione di nomi di abitanti -ello è usato di rado," for example, buranèi 'di Burano' (Venezia). Grignani and Stella (122, point $\mathrm{d}$ ) note that this outcome "è anche fenomeno monferrino."

${ }^{21}$ sorella < SORORIs, by way of analogy with fratello.
} 


\subsection{Morphology}

\subsubsection{Present}

For the 2pl., Rohlfs (\$531) quotes the forms -ati, -ade, -ai, and - $e$ for old Lombard. For Pavese, Grignani and Stella (137) note that the 1pl. outcome of -umus produced -omo (e.g., pregeromo) ${ }^{22}$ but that -emo is prevalent, both in the present and in the future (savemo, diremo, pregeremo, aremo, etc.). The $2 \mathrm{pl}$. regularly has the final vowel in $-i$ (deveti, seti, abitadi).23

For verbs in the present, there are no forms that appear similar to contemporary forms of Pavese or Milanese in Elisabetta's letters. For -ARE verbs: 1sg.: - $o$; 3sg.: - $a$; 1 pl.: -emo (se recomandemo). For -ERE verbs: 1 sg.: - - ; 3 sg.: $-e$. There are no -IRE verbs. Auxiliaries are essere: 3 sg.: $\dot{e}$, ghene, sie; 3 pl.: sono. ${ }^{24}$ avere: 1 sg.: $\dot{o}$, habio, ho; 3 sg.: a, ave; 3 pl.: anno. Irregular: 3sg.: convene; dice; pare; pò; sa. 1 pl.: pomo; stamo. 2pl.: fate. 3pl.: fano, fa (li frati fa); sano; stano; voreno 'vogliono'.

\subsubsection{Passato remoto}

Grignani and Stella $(137 \mathrm{n} 62)$ note only the form - $\dot{o}$ (and one case of $-\grave{a}$ ) in their corpus. The - $\dot{o}$ ending, for -ARE verbs, is common to both Pavese and Milanese in this period, ${ }^{25}$ as is $-i$ for -ire.

In Elisabetta's letters, for -ARE verbs: 3sg.: - $-\dot{o}$. There are no -ERE verbs. For -IRE verbs: 3sg.: -i. The only auxiliary is ESSERE: 3 sg.: fu. Irregular: disse, dixe ${ }^{26}$

${ }^{22}$ Grignani and Stella (118n4) record -ómo, -óma as endings for the $1 \mathrm{pl}$. in the present subjunctive and the imperative.

23 The -ati ending is also recorded in Mengaldo (119), Migliorini (200), Morgana "Processi" (259), and Vitale (259).

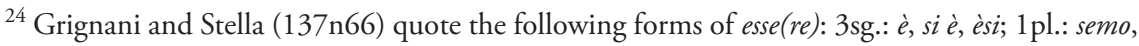
soma; 2 pl.: seti, siti; 3 pl.: suno, s’èn, sono.

${ }^{25}$ Other forms for 3sg. passato remoto include -ò (Domokos 266; Degli Innocenti 75; Morgana 248); -oe (Vitale 94); -ao (Degli Innocenti 75); and -à (Degli Innocenti 75; Rohlfs \$569).

${ }^{26}$ See the useful discussion in Wilhelm (20-21) for the problem of distinguishing both the tense and mood of dise, disse, dixe. He identifies the difficulty in using the graphemes $s s, s c$, and $x$ for $[s]$, and $s, x, z$, and $s s$ for $[\mathrm{z}]$ in northern-Italian orthography and shows how these three variants of the 3sg. of dire do not represent "realtà fonetiche chiaramente distinte" (20). These graphemes have been interpreted as different phonological variants by various scholars and 


\subsubsection{Imperfect indicative}

There are no clear differences between Pavese and Milanese for the imperfect indicative, and the category is not mentioned in Grignani and Stella (137138). Variants in Elisabetta's letters for the 1sg. are -o for the first and second conjugations. ${ }^{27}$ For the 3sg.: -ava, -eva. The forms present in Elisabetta's letters appear best characterized by the emerging Lombard koiné and, to a lesser extent, by Tuscan forms. ${ }^{28}$

For -ARE verbs: 1pl.: -aveno; 3sg.: -ava; 3pl.: -avano, aveno. For -ERE verbs: 1sg.: -o; 3sg.: -eva; 3 pl.: -evano. For -IRE verbs: -ivano. Auxiliaries are EsSERE: 3sg.: era, fira; 3pl.: erano. AVERE: aveva, eva, ghaveva, eva. FIRE: 3sg.: fira. Irregular: 3sg.: dixeva; pariva; veneva; voreva. 3 pl.: dixevano, diraveno; staraveno; venevano; voraveno.

\subsubsection{Future and conditional}

The only future form is 3sg. serà, common to both Milanese and Pavese. In Elisabetta's letters, the forms are, for -ARE verbs, 1sg.: -eve; 3sg.: -eve; and 3pl. -aveno, -eveno. The only auxiliary is ESSERE: 3sg.: serave, sareve; and 3pl.: saraveno. ${ }^{29}$ Irregular forms are 3sg.: convegnareve; farave; porave 'potrebbe'; ${ }^{30}$ voreve 'vorrebbe'.

With regard to the conditional, the only form quoted by Grignani and Stella (137) is mangirave. In Elisabetta's letters, there is only one case of analytic ave imparare 'imparerebbe. ${ }^{31}$ Domokos ("Il condizionale" 108-109) reports three ways

have therefore led to such verbs being accorded different functions, even for the same text, in different critical editions.

${ }^{27}$ Contemporary Lombard forms for 1 sg. are -ava (Domokos 265); - eva (Rohlfs \$551); -avi (Morgana "Lingua e dialetto" 237; Rohlfs \$551); and also -avo in later texts (Mengaldo 123; Morgana "Lingua e dialetto" 248).

${ }^{28}$ For Tuscan, Trolli notes that, in Giovanni Morelli's language, "la desinenza - $o$ comincia infatti solo verso la fine del Trecento ad entrare con una certa importanza nella lingua letteraria” (93). Manni's 1979 study of fifteenth-century Florentine reports -ea (39), -ava (57), and -o (57) as endings for the $1 \mathrm{sg}$.

${ }^{29}$ Grignani and Stella (137n66) record (tu) saré; serà, sarà; serano, sarano.

${ }^{30}$ Grignani and Stella (134n50) record "il futuro di «potere» [è] sempre porà, porano."

${ }^{31}$ For a study of the different ways in which the conditional was formed in old northern vernaculars, see Domokos ("Il condizionale"). On synthetic and analytic forms more generally 
of forming the conditional in the writing of Bonvesin dra Riva (c. 1240-1313). Of these, two are synthetic (Infinito + HABEBAM/HABUI) and one analytic. Based on a statistical analysis of over 3,000 lines of Bonvesin's poetry, the number of occurrences of these three types of conditional reported by Domokos (109) are
(a) synthetic conditional - Infinito + HABEBAM
(b) synthetic conditional - Infinito + HABUI
20
(c) analytic conditional
7

The occurrence of ave imparare in Elisabetta's letters corresponds to construction (c) above, that is, the imperfect indicative of AVERE + infinitive. The use of all three in Bonvesin's writing during the late Duecento suggests, as Domokos says, "l'instabilità del sistema latino classico e specialmente tardo-latino, il quale non offriva una soluzione univoca per l'espressione di questa funzione" ("Il condizionale" 111). But an examination of merchant texts sent from Milan between 1396 and 1402 shows only construction (a) to be present (Brown, "Evidence for Early Tuscanisation" 478). The eventual preference for synthetic constructions means that Elisabetta's use of an analytic form is much later than expected.

\subsubsection{Imperative}

There are no cases listed of the imperative in Grignani and Stella. The only cases in Elisabetta's writing appear to show a tendency toward the pan-Lombard koiné, and to documented forms of Milanese. These are 2pl.: fate; ${ }^{32}$ sappie, sappiti, sapiti, savi. ${ }^{33}$

\subsubsection{Subjunctive}

In the present, there is only one case for -ARE verbs. 3sg.: sia for ESSERE. In the imperfect subjunctive, there are the following cases for -ARE verbs: 3 sg.: - asse; 3 pl.:

in medieval Milanese, see Domokos ("Analytic and Synthetic Structures"). Vincent provides a useful overview of the terms synthetic and analytic and the way they have been used to describe a range of linguistic phenomena in early Italian vernaculars. For a broader discussion of analyticity and syntheticity in Romance, see the contributions by Bauer and by Schwegler.

32 Contemporary Milanese forms are fei (Domokos 272) and fatimo 'fatemi', fate (Morgana 238).

${ }^{33}$ Cf. sapiati, sapié (Bertoletti 244) and also 2sg. sapii (Degli Innocenti 77) and sapli (Domokos 272). 
-asseno. For -ERE verbs: 1sg.: -esse; 3sg.: -esse; 3pl.: -esseno. For ESSERE: 3sg.: fusse, fosse, fasse; 3pl.: fusseno. For AVERE: 3sg.: havesse; 3pl.: avesseno. Irregular verbs: 3sg.: dixesse; 3 pl.: stesseno.

\subsubsection{Past participles}

The outcome - $\dot{o}<-$ ATU(M) in verbs of the 1st class (e.g., despogliò 'spogliato', durò 'durato') is one of the traits included by Salvioni as being characteristic solely of Pavese in the fourteenth century, and, according to Stella, that would continue to distinguish it in the early fifteenth century. Domokos has identified three pastparticiple endings in the writing of Bonvesin dra Riva for -ARE verbs: -ado, -adho, $-a o$.

In Elisabetta's letters, however, the endings for past participles appear best characterized by the Lombard koiné and are not unique to any one vernacular. For -ARE verbs, the endings are -ato, -ate, -ati; for -ERE verbs, -uto, -ita; for -IRE verbs, -ite. Irregular forms are abiuto; adevenuto; chomesso; dito; disposto; fato; intexa; metudo; scripto/scripta/scritto; stata.

\section{Conclusion}

Out of the eight phenomena described by Salvioni as being particular to Pavese in the panorama of late-medieval Lombard vernaculars, only one is found to be present, and only rarely so, in Elisabetta's letters. This is surprising, especially in light of Stella's claim (183) that these eight phenomena would characterize Pavese up until the mid-1400s.

The vernacular of these letters has been purged of its most markedly local features and appears to be converging with the Lombard koiné. Rather than incorporating features of Milanese, the vernacular in Lombardy at this time was acquiring even broader linguistic elements, such as those from the koiné. At the same time, the most locally marked linguistic items no longer appear to be present with any significance in Elisabetta's writing. The formation of the koiné in Lombardy during the early fifteenth century could be termed what sociolinguist Jeff Siegel has called the pre-koiné stage, that is, a situation where "various forms of varieties in contact are used concurrently and inconsistently" and where "few [linguistic] forms have emerged as the accepted compromise" (6). The form that this compromise should take in literature became the subject of debates in the late fifteenth century during the Questione della lingua. In non-literary writing, 
however, it is impossible to speak of "accepted compromises," given that the prekoiné phase is, by definition, one in which there are multiple competing forms coming from different varieties and no authority to decide what the compromise should be. As Lurati has said, the entire north can be seen as a "regno della variazione libera" (509).

In his analysis of comunità osservanti, Bruni makes the point that "il canale dell'osservanza permette dunque l'avvio di un processo di diffusione di testi marcati localmente dal punto di vista linguistico, che riscuotono l'interesse di lettori lontani; ne risulta una compenetrazione di dialetti diversi" (4). This process, he says, contributed to the longer process of Italianization and must be explored further. The writing of Elisabetta's letters shows a similar phenomenon-the formation of an incipient koiné, one in which multiple forms are used inconsistently and that is free of the most locally marked characteristics. The linguistic variants in Elisabetta's letters appear in different texts from across Lombardy at roughly the same time. This calls into question the hegemonic role attributed to Milan in the research literature and what influence it had in the development of the koiné.

\section{Australian National University}

\section{Works Cited}

Albuzzi, Annalisa. "Il monachesimo femminile nell'Italia medioevale. Spunti di riflessione e prospettive di ricerca in margine alla produzione storiografica degli ultimi trent'anni." In Dove va la storiografia monastica in Europa? Ed. Giancarlo Andenna. Milan: Vita e Pensiero, 2001. 131-190.

Bacchiddu, Rita. Una donna carismatica e i suoi critici: Paola Antonia Negri (15081555) e i primi Barnabiti. Diss. Fondazione Collegio S. Carlo di Modena, 2003.

Bauer, Brigitte L.M. "'Synthetic' vs. 'Analytic' in Romance: The Importance of Varieties." In Historical Romance Linguistics: Retrospective and Perspective. Ed. Randall S. Gess and Deborah Arteaga. Amsterdam and Philadelphia: John Benjamins, 2006. 287-304.

Bertoletti, Nello. "Una lettera in volgare del Trecento dal carcere di Modena." Studi linguistici italiani 27 (2000): 233-247. 
Bongrani, Paolo, and Silvia Morgana. "La Lombardia." In Litaliano nelle regioni. Lingua nazionale e identità regionali. Ed. Francesco Bruni. Turin: UTET, 1992. 84-142.

. "La Lombardia." In Litaliano nelle regioni. Testi e documenti. Ed. Francesco Bruni. Turin: UTET, 1994. 101-170.

Borgogno, Giovanni Battista. "Note sistematiche sulla lingua di documenti mantovani dei secoli XV e XVI." Atti e memorie dell'Accademia Virgiliana di Mantova 46 (1978): 33-133.

Brown, Joshua. "Evidence for Early Tuscanisation in the Commercial Letters from the Milanese Merchant Giovannino da Dugnano (?-1398) in the Datini Archive in Prato." Italica 89.4 (2012): 464-488.

. "Language Variation in Fifteenth-Century Milan: Evidence of Koineization in the Letters (1397-1402) of the Milanese Merchant Giovanni da Pessano." Italian Studies 68.1 (2013): 57-77.

Bruni, Francesco. "Appunti sui movimenti religiosi e il volgare italiano nel Quattro-Cinquecento." Studi linguistici italiani nuova serie, 9 (1983): 3-30.

Caprioli, Adriano, Antonio Rimoldi, and Luciano Vaccaro, eds. Diocesi di Pavia. Storia religiosa della Lombardia. Brescia: La Scuola, 1995.

Colombo, Michele. "Una confessio in volgare milanese del 1311." Studi linguistici italiani 36.1 (2010): 3-26.

Crusenio, Nicola. Monasticon Augustinianum. Augsburg: Johannes Hertsroy, 1622.

Daniele, Antonio. "Adolfo Mussafia e la genesi della teoria della koinè alto-italiana." In Koinè in Italia. Dalle origini al Cinquecento. Ed. Glauco Sanga. Bergamo: P. Lubrina, 1991. 229-240.

Degli Innocenti, Mario. L'Elucidario. Volgarizzamento in antico milanese dell' «Elucidarium» di Onorio Augustodunense. Padova: Antenore.

Domokos, György. "Il condizionale nei volgari italiani settentrionali." Verbum 5.1 (2003): 103-111.

. "Analytic and Synthetic Structures in Medieval Milanese." In Language and Language-Processing. Ed. Pawel Karnowski and Imre Szigeti. Frankfurt am Main: Lang, 2006. 21-29.

. "La morfologia verbale del milanese antico Bonvesin dra Riva." Verbum 9.2 (2007): 261-277.

Foerster, Wendelin. "Antica parafrasi lombarda del «Neminem laedi nisi a se ipso» di S. Giovanni Grisostomo (cod. Torin. N. V. 57).” Archivio glottologico italiano 7 (1880-1883): 1-120. 
Forzatti Golia, Giovanna. "Le strutture ecclesiastiche in età medievale." In Diocesi di Pavia. Ed. Adriano Caprioli, Antonio Rimoldi, and Luciano Vaccaro. Storia religiosa della Lombardia. Brescia: La Scuola, 1995. 117-156.

Grignani, Maria Antonietta, and Angelo Stella, eds. Antichi testi pavesi. Pavia: Tipografia del Libro, 1977.

Lurati, Ottavio. "Aree linguistiche, III. Lombardia e Ticino." In Lexikon der romanistischen Linguistik. Ed. Günter Holtus, Michael Metzeltin, and Christian Schmitt. Tübingen: Niemeyer, 1988. 485-516.

Manni, Paola. "Ricerche sui tratti fonetici e morfologici del fiorentino quattrocentesco.” Studi di grammatica italiana 8 (1979): 115-171.

Massariello Merzagora, Giovanna. Lombardia. Pisa: Pacini, 1988.

Mengaldo, Pier Vincenzo. La lingua del Boiardo lirico. Florence: Olschki, 1963.

Mens, Alcantara. "Beghine, begardi, beghinaggi." In Dizionario degli Istituti di Perfezione. Ed. Guerrino Pelliccia and Giancarlo Rocca. Vol. 1. Rome: Edizioni paoline, 1980. 1165-1180.

Migliorini, Bruno. Storia della lingua italiana. Florence: Sansoni, 1960.

Milani, Felice, and Angelo Stella, eds. Parlà 'd Varlaeca. Lingua e dialetto a Pavia dal '300 al '900. Pavia: Logos International, 1985.

Morgana, Silvia. "Processi di standardizzazione nei documenti dell'Archivio del Duomo di Milano (sec. XVI-XVII-XVIII)." In Linguistica storica e cambiamento linguistico. Ed. Luciano Agostiniani, Patrizia Bellucci Maffei, and Matilde Paoli. Rome: Bulzoni, 1985. 251-262.

. "Lingua e dialetto nelle scritture di semicolti milanesi del '600.” Filologia moderna 9 (1987): 209-264.

. Breve storia della lingua italiana. Rome: Carocci, 2009. . Storia linguistica di Milano. Rome: Carocci, 2012.

Natale, Alfio R., Adele Bellù, and Andreina Bazzi. "Sezione di Archivio di Stato di Milano." In Guida generale degli archivi di Stato italiani. Ed. Piero D’Angiolini and Claudio Pavone. Vol. 2. Rome: Ministero per i beni culturali e ambientali, Ufficio centrale per i beni archivistici, 1981. 891-965.

Persico, Gaetano. "Il volgare illustre predantesco nell'Italia Settentrionale." Saggi di Umanismo Cristiano 4.4 (Dec. 1949): 55-71.

Rano, Balbino. “Annunziate di Lombardia." In Dizionario degli Istituti di Perfezione. Ed. Guerrino Pelliccia and Giancarlo Rocca. Vol. 1. Rome: Edizioni paoline, 1974. 664-667. 
Regis, Riccardo. "Koinè dialettale. Dialetto di koinè, processi di koinizzazione." Rivista italiana di dialettologia 35 (2012): 7-36.

. "Note su koinè." Romanische Forschungen 124.1 (2012): 3-16.

Rho, Emilio. "Testi in volgare lombardo del Trecento." Archivio storico lombardo nuova serie, 2 (1937): 67-118.

Rohlfs, Gerhard. Grammatica storica della lingua italiana e dei suoi dialetti. Turin: Einaudi, 1966-1969.

Salvioni, Carlo. "Dell'antico dialetto pavese." Bollettino della Società Pavese di Storia Patria 2 (1902): 193-251.

Sanga, Glauco. Dialettologia lombarda. Lingue e culture popolari. Pavia: Aurora, 1984.

. “Due Lombardie." Rivista italiana di dialettologia 12 (1989): 173-95. , ed. Koinè in Italia. Dalle origini al Cinquecento. Bergamo: P. Lubrina, 1991.

. "Lombardy." In The Dialects of Italy. Ed. Martin Maiden and Mair M. Parry. London: Routledge, 1997. 253-259.

Schwegler, Armin. Analyticity and Syntheticity. A Diachronic Perspective with Special Reference to Romance Languages. Berlin: Mouton De Gruyter, 1990.

Sebastiani, Lucia. "Da Bizzocche a Monache." In Il monachesimo femminile in Italia dall'alto Medioevo al secolo XVII. A confronto con l'oggi. Ed. Gabriella Zarri. Il Segno dei Gabrielli: Negarine di S. Pietro in Cariano, 1997. 193-218. Sgrilli, Paola. "L'espansione del toscano nel Trecento." In La Toscana nel secolo XIV: Caratteri di una civiltà regionale. Ed. Sergio Gensini. Pubblicazioni del Centro di Studi sulla Civiltà del Tardo Medioevo. Pisa: Pacini Editore, 1988. 425-464.

Siegel, Jeff. "Introduction: Controversies in the Study of Koines and Koineization." International Journal of the Sociology of Language 99 (1993): 5-8.

Stella, Angelo. "Lombardia." In Storia della lingua italiana. III. Le altre lingue. Ed. Luca Serianni and Pietro Trifone. Turin: G. Einaudi, 1994. 153-212.

Stella, Angelo, and Cesare Repossi. “Tra latino e volgare.” In Parlà 'd Varlaeca. Lingua e dialetto a Pavia dal '300 al '900. Ed. Felice Milani and Angelo Stella. Pavia: Logos International, 1985. 1-29.

Tomasin, Lorenzo. "Gli studi sugli antichi volgari settentrionali." Bollettino di italianistica nuova serie, 4.2 (2007): 71-85.

Trolli, Domizia. "La lingua di Giovanni Morelli." Studi di grammatica italiana 2 (1972): 51-153. 
Trumper, John. "Ricostruzione nell'Italia settentrionale: sistemi consonantici." In Problemi della ricostruzione linguistica. Ed. Raffaele Simone and Ugo Vignuzzi. Rome: Bulzoni, 1977. 259-310.

Trumper, John, and Marta Maddalon. "Converging Divergence and Diverging Convergence: the Dialect-Language Conflict and Contrasting Evolutionary Trends in Modern Italy." In Variation and Convergence: Studies in Social Dialectology. Ed. Peter Auer and Aldo di Luzio. Berlin: de Gruyter, 1988. 216-258.

Vincent, Nigel. "Synthetic and Analytic Structures." In The Dialects of Italy. Ed. Martin Maiden and Mair M. Parry. London: Routledge, 1997. 99-105.

Viscardi, Antonio, and Maurizio Vitale. "La cultura milanese nel secolo XIV." Storia di Milano. Milan: Fondazione Treccani degli Alfieri, 1955. 571-634. Vitale, Maurizio. La lingua volgare della cancelleria visconteo-sforzesca nel Quattrocento. Varese-Milano: Istituto Editoriale Cisalpino, 1953. . "La lingua volgare della cancelleria sforzesca nell'età di Ludovico il Moro." In Milano nell'età di Ludovico il Moro. 2 vols. Milan: Archivio Storico Civico e Biblioteca Trivulziana, 1983. . "Cultura e lingua a Milano nel Trecento." In Petrarca e la Lombardia. Ed. Giuseppe Frasso, Giuseppe Velli, and Maurizio Vitale. Rome and Padua: Antenore, 2005. 31-49

Wilhelm, Raymund. Bonvesin da la Riva. La Vita di Sant'Alessio. Edizione secondo il codice Trivulziano 93. Tübingen: Niemeyer, 2006.

Wilhelm, Raymund, Federica De Monte, and Miriam Wittum. Tradizioni testuali e tradizioni linguistiche nella Margherita lombarda. Edizione e analisi del testo trivulziano. Heidelberg: Winter, 2011. 
